UDK 336:366.542](73+4-672EU)

https://doi.org/10.18485/union_pf_ccr.2021.ch19

Ph.D. Virág Blazsek*

\title{
FINANCIAL CONSUMER PROTECTION IN THE U.S. AND THE E.U. A PREVENTIVE BUILDING BLOCK OF BANKING BAILOUT LAW
}

\begin{abstract}
This article evaluates the post-2008 legal/regulatory framework of financial consumer protection in the U.S. and the E.U. and argues that financial consumer protection is not sufficiently robust to have a significantly positive impact on financial stability. To turn this around, the article proposes a novel analysis of financial consumer protection and the strengthening of financial consumer protection with a broader, systemic stability-based argument, rather than a narrower, primarily competition law-based argument. This article proposes a more encompassing consumer protection definition, a catalog of chief areas and tools, and a more interdisciplinary approach in this new era that emphasizes the importance of financial education and international collaboration.
\end{abstract}

Key words: financial consumer protection, financial stability, bailout, financial education, financial literacy, international consumer protection, E.U. financial consumer protection, Consumer Financial Protection Bureau, Dodd-Frank Act, Bank Recovery and Resolution Directive.

\section{INTRODUCTION}

Banks go bankrupt when their customers go bankrupt, therefore, the quality of banks' portfolios matters. In my recent book, Banking Bailout Law: A Comparative Study of the United States, United Kingdom and the European Union, I briefly deal with the importance of financial consumer protection and I propose a novel approach: The consideration of financial consumer protection as a preventive building block of banking bailout law. ${ }^{1}$ This article elaborates on

\footnotetext{
* Attorney at the United Nations Joint Staff Pension Fund's Office of Investment Management in New York, e-mail: blazsek@gmail.com.

1 The views expressed herein do not necessarily reflect the positions of the United Nations. This article builds upon the author's recent book, Banking Bailout Law: A Comparative Study of the United States, United Kingdom and the European Union (Routledge, New York, U.S. \& London, U.K., 2020). The author wishes to thank the participants of the Protection of the Collective Interests of Consumers Conference organized by the Union University Law School and the Institute for Comparative Law in Belgrade, Serbia [via Zoom] on October 24, 2020 for helpful comments, including Tibor Tajti, Katarina Ivancevic, Catalin-Gabriel Stanescu, Williams C. Iheme, Matthew Copley, and the anonymous reviewers.
} 
that idea and argues that such approach will result in stronger financial consumer protection and it will also have a significant, positive impact on financial stability.

The term, 'banking bailout law' refers to those elements of the legal/regulatory framework related to the financial sector which serve the purpose of either the prevention or management of systemic financial crisis and related bank insolvencies. I argue in my book that consumer protection is probably the most important aspect among the preventive building blocks of banking bailout law. As Engel and McCoy note, reckless subprime lending practices were among the top reasons for the outbreak of the 2008 crisis. ${ }^{2}$ The real estate bubble would not have had such a devastating effect if banks' mortgage portfolios had been less risky and if strong financial consumer protection provisions had been in place in the U.S.

Financial consumer protection aims at curing the asymmetry that exists between financial institutions and their consumers (i.e., individual customers buying services for their own use) in terms of information and market position (both have access to information and the ability to understand the available information). There are two major categories of legal/regulatory tools: (1) mandatory disclosure of terms and conditions to assist the financial consumer in their decision-making, and (2) merit regulation with respect to setting terms and conditions, such as minimum requirements for the borrower's financial capacity, rate-setting, or prohibiting certain conditions or services, such as variable interest rates that are difficult to calculate. Within merit regulation, consumer credit rating is a sub-category that assists the financial service provider in the decision-making (whether to provide financial services or not to a consumer and with what conditions).

In the post-2008 era, also accepting the limits of law and promoting interdisciplinarity, instead of further merit regulation, this article proposes to rather build upon a cooperative approach between the consumer and the financial sector which can be based on the approach of a shared interest of these two in

Blazsek, V., 2020, Banking Bailout Law: A Comparative Study of the United States, United Kingdom and the European Union, New York, U.S. \& London, U.K., Routledge, pp. 194-195; for a brief book-overview see Blazsek, V., Banking Bailout Law, Blue Sky Blog Columbia Law School, New York, NY, U.S.

2 See generally Engel, K. C., McCoy, P., 2011, The Subprime Virus: Reckless Credit, Regulatory Failure, and Next Steps, Oxford, U.K., Oxford University Press; see also Gerding, E. F., 2009, The Subprime Crisis and the Link Between Consumer Financial Protection and Systemic Risk, FIU Law Review, 4, p. 461; McLean, B., Nocera, J., 2010, All The Devils Are Here, The Hidden History of the Financial Crisis, New York, NY, U.S., Portfolio/Penguin; Block-Lieb, S., Janger, E. J., 2006, The Myth of the Rational Borrower: Rationality, Behaviorism, and the Misguided 'Reform' of Bankruptcy Law, Texas Law Review, Vol. 84, pp. 1481-1565; Janger, E. J., Block-Lieb, S., 2010, Consumer Credit and Competition: The Puzzle of Competitive Credit Markets, European Competition Journal, Vol. 6, No. 68; The American Mortgage system: Crisis and Reform, 2011, University of Pennsylvania Press, Philadelphia, PA, U.S. [Chapter by Engel, K. C., Fitzpatrick, T. J., A Framework for Consumer Protection in Home Mortgage Lending]; Bostic, R. W. et al., 2008, State and Local Anti-Predatory Lending Laws: The Effect of Legal Enforcement Mechanisms, Journal of Economics and Business, Vol. 60, p. 47. 
financial stability. This article proposes the strengthening of consumers' financial education, an area that is underdeveloped on both sides of the Atlantic. There are a variety of safety nets in place, including deposit insurance and investor compensation schemes as well as data protection. If financial consumers will be more familiar with all those safety nets this could increase their confidence or trust in the financial system, which would also contribute to financial stability in a positive way. The article also highlights examples for international institutionalized cooperation in this area, such as the International Financial Consumer Protection Organisation (hereinafter, "FinCoNet"), that is interpreted as a positive development from a financial stability perspective. ${ }^{3}$

\section{A MORE ENCOMPASSING FINANCIAL CONSUMER PROTECTION DEFINITION}

Banks have consumer, commercial, and investment business lines. Financial consumer services can be grouped into four categories: (1) deposit taking, (2) lending, (3) providing payment services, and (4) providing services related to consumer investments (including private pensions, which is a large part of consumer investments). A further area of consumer financial services is (5) consumer insurance. Financial consumer protection is not only related to the hardship of performance or providing accurate and adequate information for the consumer. This article builds upon a much more encompassing definition of financial consumer protection that covers all the above areas of financial consumer services and the consumer protection tools related to them, including financial consumer data protection, deposit insurance, and investor compensation schemes.

The following table summarizes the elements of a more encompassing financial consumer protection definition:

\begin{tabular}{|l|l|l|}
\hline $\begin{array}{l}\text { Financial } \\
\text { Service-type }\end{array}$ & $\begin{array}{l}\text { Universal Financial Consumer } \\
\text { Protection Tools }\end{array}$ & $\begin{array}{l}\text { Financial Service-specific } \\
\text { Consumer Protection } \\
\text { Tools }\end{array}$ \\
\hline Payment & $\begin{array}{l}\text { 1. } \begin{array}{l}\text { Financial education in primary and } \\
\text { high school (in cooperation with } \\
\text { universities) }\end{array} \\
\text { 2. } \begin{array}{l}\text { Cooperation and trust-building } \\
\text { among service providers, consum- } \\
\text { ers, and supervisory authorities }\end{array}\end{array}$ & $\begin{array}{l}\text { 2. Insurance provided by } \\
\text { bank card companies } \\
\text { against fraud }\end{array}$ \\
3. $\begin{array}{l}\text { Digital financial and ownership } \\
\text { data protection of payment } \\
\text { Competition (alternatives for the } \\
\text { consumer and prevention of abuse } \\
\text { of dominant position) }\end{array}$ & \\
\hline
\end{tabular}

3 See International Financial Consumer Protection Organisation, 2020, (http://www.finconet. org/about/, 19. 11. 2020). 


\begin{tabular}{|c|c|c|}
\hline $\begin{array}{l}\text { Financial } \\
\text { Service-type }\end{array}$ & $\begin{array}{l}\text { Universal Financial Consumer } \\
\text { Protection Tools }\end{array}$ & $\begin{array}{l}\text { Financial Service-specific } \\
\text { Consumer Protection } \\
\text { Tools }\end{array}$ \\
\hline Credit & \multirow{4}{*}{$\begin{array}{l}\text { 5. Consumer ratings (scope, control, } \\
\text { use of ratings) } \\
\text { 6. Anti-discrimination rules } \\
\text { 7. Disclosure of accurate, full, and } \\
\text { well-presented information } \\
\text { 8. Transparent fees } \\
\text { 9. Access to dispute resolution for in- } \\
\text { dividuals and availability of class ac- } \\
\text { tions for consumer groups } \\
\text { 10. Bankruptcy proceedings for indi- } \\
\text { viduals } \\
\text { 11. Supervision by state agencies } \\
\text { 12. Existence of Civil financial consum- } \\
\text { er protection organizations } \\
\text { 13. International cooperation among } \\
\text { state agencies } \\
\text { 14. Research studies and empirical data } \\
\text { collection and analysis by interna- } \\
\text { tional organizations }\end{array}$} & $\begin{array}{l}\text { Financial hardship and } \\
\text { default-related assistance } \\
\text { mostly related to housing } \\
\text { mortgages }\end{array}$ \\
\hline Deposit & & $\begin{array}{l}\text { Deposit Insurance } \\
\text { Schemes }\end{array}$ \\
\hline Investment & & $\begin{array}{l}\text { Investor Compensation } \\
\text { Schemes }\end{array}$ \\
\hline Insurance & & $\begin{array}{l}\text { Extension of investor } \\
\text { Compensation Schemes } \\
\text { for life insurance-related } \\
\text { fraud }\end{array}$ \\
\hline
\end{tabular}

To the best of my knowledge, 'Consumer protection law' does not have a fixed definition, nor does it have a clearly defined theoretical framework, but rather it is a practical term used for legal/regulatory provisions that serve the purpose of protecting the financial consumer. Consumer protection law usually refers to unfair business practices rooted in competition law, particularly in the E.U. But, the financial sector is in the dynamic process of digitalization, and in this new, unfolding era where ownership and money are being stored digitally, digital currencies and blockchain technologies are becoming increasingly more important, and the adequate protection of individuals is paramount from the perspective of systemic stability. ${ }^{4}$ A more encompassing definition of financial consumer protection will serve consumers in a better way, allow for further layers of arguments in favor of financial consumer protection, and advance the ultimate goal of financial law and regulation: financial stability. ${ }^{5}$

It is argued in this article that financial merit regulation may be beneficial for the consumer in some areas, see for example the legal developments in payment services in the E.U. where under the Single Euro Payments Area (SEPA) same-day or one-day bank transfers are available within the E.U. By contrast, in

4 See Loo, R. van, 2019, Broadening Consumer Law: Competition, Protection, and Distribution, Notre Dame Law Review, Vol. 95, Issue 1.

5 The two major waves of financial law and regulation were enacted following the 1929 and the 2008 global financial crisis and are aimed at preventing future financial crises of similar gravity. 
the U.S. a consumer bank transfer takes 2-3 days usually. The reason for this is because in the U.S., state and federal statutes, regulations, and case law govern the payment system which makes it difficult to create a fully integrated system. Even though the E.U.s SEPA is for euro payments only, it significantly reduces the overall cost to the European economy which is highly beneficial for the consumer and financial stability. This example is noted here to illustrate that the legislator and the regulator can reach positive results through merit regulation in certain areas. However, given the already extensive financial regulatory framework in the post-2008 era, this article underscores the importance of a more cooperative and interdisciplinary approach rather than further merit regulation. International recommendations also highlight that there are duplications of the regulatory efforts. ${ }^{6}$ The strengthening of financial consumer education and international cooperation are the areas where financial consumer protection can improve its effectiveness the most in the upcoming years. This approach will contribute to greater financial stability.

\section{A FINANCIAL STABILITY-BASED APPROACH OF THE POST-2008 FINANCIAL CONSUMER PROTECTION FRAMEWORK}

\subsection{INTERNATIONAL DEVELOPMENTS}

While this article relies on examples from the U.S. and the E.U., the international legal/regulatory developments need to be discussed first because a large part of the national laws and regulations are based on those developments and their recommendations. On the most general level, Pillar III of the Basel Accord, the ultimate aim of which is to strengthen global financial stability, proposes, among others, increased disclosure and transparency in the financial sector, which overlaps with one of the main tools of financial consumer protection. ${ }^{7}$ Increased market discipline and transparency are positive developments, but consumers may lack resources (knowledge, time, etc.) to digest and use the information that is available. Therefore, transparency-related requirements are primarily scrutinized by financial supervisory authorities (and to some extent by civil organizations specialized in financial consumer protection). As financial services are becoming increasingly more digitalized and cross-border in nature, authorities have realized the importance of international cooperation and coordination.

There are both general and financial services-specific international consumer protection organizations. In the area of international financial consumer protection, the Organization for Economic Co-operation and Development

6 OECD, Recommendation on Consumer Protection for E-commerce, 2016, at point 54 on p. 20, (http://www.oecd.org/sti/consumer/ECommerce-Recommendation-2016.pdf, 19. 11. 2020).

7 See generally Basel III: international regulatory framework for banks, (https://www.bis.org/ bcbs/basel3.htm?m=3\%7C14\%7C572, 19. 11. 2020). 
(hereinafter, "OECD") provides valuable comparative research studies and recommendations.

The OECD's Committee on Consumer Policy (hereinafter, "CCP") addresses a broad range of consumer issues and helps public authorities to enhance the development of effective consumer policies. ${ }^{8}$ Its tools include research and analysis, developing policy guidelines, and exchanging information on current and emerging issues and trends both among governments and with other stakeholders. The CCP works closely with experts from civil society and the business community including those from non-member states. It particularly focuses on consumer (including financial consumer) confidence in the digital economy: "enhancing consumer trust remains a cornerstone for success in a dynamic and complex e-commerce marketplace." The OECD Recommendation on Consumer Protection in E-commerce (hereinafter, OECD Recommendation) summarizes recommendations on fair business practices, information disclosures, payment protections, unsafe products, dispute resolution, enforcement, and education. ${ }^{10}$ The OECD Recommendation was first published in 1999, and its most recent revision took place in 2016.

As technological developments and digitalization are reshaping the financial sector, the OECD Recommendation has become increasingly more relevant and specifically for the financial sector, and even though its scope is general it is not limited to that sector. The OECD Recommendation also emphasizes the importance of global cooperation, communication, and joint initiatives at the international level among governments and stakeholders. ${ }^{11}$ Instead of further regulatory efforts, it rather emphasizes "the use of existing international networks." ${ }^{2}$

Besides the OECD, the World Bank is the other most important international organization in the area of financial consumer protection. The World Bank's chief publication in this area is the 254-pages long Good Practices for Financial Consumer Protection (hereinafter, Good Practices) which was first published in 2012 and most recently updated in $2017 .{ }^{13}$ The Good Practices is a comprehensive reference tool for policymakers that consolidates the latest research and international guidance specifically in the area of financial consumer protection. The Good Practices follows a functional structure based on the types of financial services (deposit and credit products and services; Insurance; private pensions; securities; retail payment services) and it also includes recommendations on credit reporting systems and financial capability.

8 See generally OECD Directorate for Science, Technology and Innovation, Consumer policy, (http://www.oecd.org/sti/consumer/, 19. 11. 2020).

9 See generally OECD, (http://www.oecd.org/sti/consumer/consumersinthedigitaleconomy. htm, Nov. 19, 2020).

10 OECD, Recommendation on Consumer Protection for E-commerce, 2016, (http://www.oecd. $\mathrm{org} / \mathrm{sti} /$ consumer/ECommerce-Recommendation-2016.pdf, 19. 11. 2020).

11 Id. 9, at point 54, pp. 19-20.

12 Id. 9, at point 54, p. 20.

13 World Bank, Good Practices for Financial Consumer Protection, 2017, (https://www.worldbank.org/en/topic/financialinclusion/brief/2017-good-practices-for-financial-consumer-protection, 19. 11.2020). 
The Good Practices includes recommendations on the legal and supervisory framework, disclosure and transparency, fair treatment (e.g., unfair terms and conditions, unfair practices, sales practices), data protection and privacy, and dispute resolution mechanisms. The Good Practices relies on a more encompassing financial consumer protection definition, also proposed by this article. It reflects this articles' argument that financial consumer protections and systemic stability cannot be separated, because financial consumer protection is an important building block of systemic stability and of the legal framework that promotes systemic stability. See for example the part of the Good Practices which deals with the bankruptcy of individuals and the insolvency of financial institutions. ${ }^{14}$ For example, the Good Practices recommends that "depositors should enjoy higher priority than other unsecured creditors in the liquidation process of a financial service provider." ${ }^{\prime 5}$ The reason for this is that it is recognized by the Good Practices that "the global financial crisis of 2008 highlighted the importance of financial consumer protection for the long-term stability of the world financial system." 16

The next international organization mentioned here is the International Consumer Protection and Enforcement Network (hereinafter, ICPEN) is a general, non-profit organization composed of consumer protection authorities from over 65 countries. ${ }^{17}$ The organization focuses on both consumer education and sharing of industrial best practices with a special focus on cross-border issues and fraud prevention.

The "econsumer.gov" Website was created by ICPEN in 2001 and it is a partnership of more than 35 consumer protection agencies around the world and is an international consumer protection organization of general scope. The Website enables consumers to submit international fraud complaints Online and bring them to the attention of the member agencies in 6 languages. ${ }^{18}$ The organization published reports from which agencies can keep track of the fraud trends which also allows the agencies to develop and tailor preventive measures in line with those trends. In terms of the credit- and loan-related fraud complaints the chief topics are: credit cards, credit reporting, mortgages, loan services, counterfeit check scams, debt collection practices, debt management, credit counseling, and messages promising money from a foreign country in return for payment, bank account details, or other personal information. ${ }^{19}$

In February 2011, the G20 called on the OECD, the Financial Stability Board ("FSB"), and other relevant international organizations to develop common principles on financial consumer protection. The 'G20 High-Level Principles on Financial Consumer Protection' (hereinafter,) were endorsed at the G20 meeting

14 Supra note 13 , at 53-61.

15 Supra note 13 , at 55.

16 Supra note 13 , at 1.

17 See International Consumer Protection and Enforcement Network, (https://icpen.org/initiatives, 19. 11 2020).

18 See generally https://econsumer.gov/\#crnt, 19. 11. 2020).

19 Ibid. 
in October 2011. ${ }^{20}$ As stated in the Principles document, "Consumer confidence and trust in a well-functioning market for financial services promotes financial stability, growth, efficiency and innovation over the long term. (...) financial consumer protection should be reinforced and integrated with other financial inclusion and financial education policies. This contributes to strengthening financial stability." ${ }^{21}$

The Principles include a set of valuable recommendations for legislators and regulators globally. While the Principles include the "Protection of Consumer Assets against Fraud and Misuse" and "Protection of Consumer Data and Privacy," they are not prioritized among the Principles. This article argues that they should be prioritized as with the exponential technological developments and digitalization of ownership registration and payments, because these will be the most important aspects of consumer protection (and financial stability). ${ }^{22}$ The Principles includes "Financial Education and Awareness" in a more detailed manner, which resonates with the main arguments mentioned in the Introduction above. ${ }^{23}$

The Principles does not include the protection of consumer investments. It is argued by this author that the protection of consumer investments should be added to the Principles. Consumer investments, mostly in pension funds and mutual funds, represent a significant segment of the money intermediated through the financial system, therefore, they are important from the perspective of systemic stability. Major tools in this area are investor compensation schemes. ${ }^{24}$ Similarly to deposit insurance, which is part of the legal/regulatory framework on both sides of the Atlantic, investor compensation is available up to a limit, but does not provide unlimited protection against fraud (there is a threshold in all of the above-mentioned jurisdictions). ${ }^{25}$ Yet, these schemes were primarily set up to sustain consumer investor confidence and systemic stability, and they exemplify the best way in which consumer protection can be better understood and more efficiently promoted on the basis of the systemic stability argument. The Principles do not include guidance regarding the application of the bail-in tool which can arise in the context of bank resolution, in particular in the E.U. Given the ongoing lawsuits related to the private bailout and bail-in in the 2017 Banco Popular - Banco Santander case (when that bank was purchased

20 See G20 High-Level Principles on Financial Consumer Protection, 2011, (http://www.oecd.org/ daf/fin/financial-markets/48892010.pdf, 19. 11. 2020); See also at http://www.oecd.org/daf/ fin/financial-markets/financialconsumerprotection.htm, 19. 11. 2020.

21 Id. (Principles), at 4 (Framework).

22 Id. (Principles), at 7 (Principles No. 7 and 8).

23 Id. (Principles), at 6 (Principles No. 5).

24 Supra note 2 (Banking Bailout Law), at 113 (E.U.), 128 (U.K.), 138 (Spain), and 148 (Hungary); Directive 97/9/EC of the European Parliament and of the Council of 3 March 1997 on investor-compensation schemes (OJ L 084, 26/3/1997, 22-31) ('Investor Compensation Scheme Directive').

25 Ibid.; The thresholds are as follows: U.S.: USD500,000.00; U.K.: USD120,000.00; E.U.: EUR100,000.00; Spain: EUR100,000.00; Hungary: EUR100,000.00; Directive 2014/49/EU of the European Parliament and of the Council of 16 Apr. 2014 on deposit guarantee schemes (OJ L 173 of 12 June 2014) ('Deposit Guarantee Scheme Directive'). 
by Banco Santander), and the private savings negatively affected by the application of the bail-in tool, this is a valid point to raise. This article argues that individual savings should not be affected, at least up to a threshold similarly to deposit insurance, by the bail-in. This issue would require further analysis as it has remained unresolved to date. ${ }^{26}$

In 2013, various leading central banks and financial supervisory authorities went beyond information-sharing and decided to establish the International Financial Consumer Protection Organisation (FinCoNet). ${ }^{27}$ The FinCoNet is focused on banking and credit consumer issues. Currently, there about 30 member organizations which include the U.K. Financial Conduct Authority, the Central Bank of France, the Central Bank of Spain, and the People's Bank of China, and such authorities collaborate "to promote and execute robust and effective supervisory standards and practices and by the sharing of best practices among supervisors." ${ }^{28}$

Finally, the Ten Principles of the United Nations Global Compact aim at supporting companies in the transition to sustainable development and to leveraging corporate finance and investments toward the realization of the Sustainable Development Goals. ${ }^{29}$ The main underlying goal of these efforts and the Sustainable Development Goals is financial systemic stability and placing the consumer in a better position globally through a more collaborative approach and voluntary compliance by service providers. ${ }^{30}$

For the future path, the main post-2008 developments in financial consumer protection will be summarized in the U.S. and the E.U.

\subsection{THE UNITED STATES}

Consumer protection is based on competition or antitrust law less in the U.S. than in the E.U. In the U.S., prior to the 2008 financial crisis, consumer protection laws were predominantly state laws. Title X of the Dodd-Frank Act (a.k.a. the "Consumer Financial Protection Act of 2010") created a federal financial consumer protection bureau for the first time in the U.S., the Consumer Financial Protection Bureau (hereinafter, CFPB), which aims at ensuring fair, transparent, and uniform standards for consumer financial services. ${ }^{31}$ Title $\mathrm{X}$

26 ECB determined Banco Popular Español S.A. was failing or likely to fail, 2017, ECB Press Release, (https://www.bankingsupervision.europa.eu/press/pr/date/2017/html/ssm.pr170607. en.html, 19. 11. 2020).

27 Supra note 4.

28 Ibid.

29 United Nations, Global Compact, Sustainable Finance, (https://www.unglobalcompact.org/ sdgs/sustainablefinance, 19. 11. 2020).

30 United Nations, A Global Compact for Sustainable Development, (https://d306pr3pise04h. cloudfront.net/docs/issues_doc\%2Fdevelopment\%2FGCforSDbrochure.pdf, 19. 11. 2020).

31 See Dodd-Frank Wall Street Reform and Consumer Protection Act (Pub L 111-203, H.R. 4173) (7/21/2010), at Title X; see also Consumer Financial Protection Bureau, (https://www. consumerfinance.gov/, 19. 11. 2020); Kennedy, L. J., McCoy, P. A., Bernstein, E., 2012, The Consumer Financial Protection Bureau: Financial Regulation for the twenty-First Century, Cornell Law Review, 97, p. 1141, (http://scholarship.law.cornell.edu/clr/vol97/iss5/4, 19. 11. 2020). 
preserves state laws as long as the state laws do not conflict with federal laws or regulations. $^{32}$

Besides the CFPB, a new federal agency specialized in financial consumer protection, the Making Homes Affordable program of the U.S. Treasury and the complete reorganization of the home mortgage-financing activities of Fannie Mae and Freddie Mac were the most significant elements of the post-2008 reforms. ${ }^{33}$ Fannie Mae and Freddie Mac define the terms and conditions for U.S. housing mortgage loans which directly affect consumers. Currently, Fannie Mae and Freddie Mac are in public hands, but there has been an ongoing debate about their re-privatization which is now delayed because of the COVID-19 pandemic and overall, does not seem realistic in the upcoming years. ${ }^{34}$ This issue is relevant from a financial consumer protection perspective because Fannie Mae and Freddie Mac refinance $90 \%$ of the U.S. housing mortgage market and the question can be raised of: What would happen to the terms and conditions these entities set for housing mortgages if they would be re-privatized? This article argues that because of the size and systemic importance of these two entities, this issue will need to be tackled and resolved before any re-privatization can take place.

An important difference between the U.S. and the E.U. is that traditionally, the enforcement of financial consumer protection laws has been done mostly through private enforcements in the U.S., frequently via class actions and settlements, whereas in the E.U., enforcement has been primarily undertaken by state authorities, through administrative bodies. This difference again highlights the novelty of the CFPB within the U.S. financial consumer protection framework, strengthening administrative actions against market players rather than private actions. The CFPB has the authority to pass rules to ensure fair, transparent, and uniform standards for credit cards, mortgages, auto loans, student loans, and other consumer financial services. ${ }^{35}$

The CFPB can take legal action against entities that violated federal consumer financial laws. Because of the novelty of the CFPB organization within the U.S. legal system, there have been lawsuits regarding its constitutionality, and in June 2020, the U.S. Supreme Court ruled that the structure of CFPB is unconstitutional because it violates the separation of powers. ${ }^{36}$ "The agency may (...)

32 Supra note 29, 12 U.S.C. $\$ 5551$.

33 Fannie Mae and Freddie Mac are two government-sponsored entities in the U.S. through which $90 \%$ of the home mortgage market is financed in the U.S. These entities were originally in private hands, but as part of their 2008 rescue, the U.S. Federal Government nationalized them, and they have remained in government ownership and control to date (19. 11. 2020).

34 Ausick, P., Do Investors Think Fannie Mae, Freddie Mac Can Be Privatized Before Trump's Term Ends?, 2020, Blog Post, (https://247wallst.com/banking-finance/2020/11/23/do-investorsthink-fannie-mae-freddie-mac-can-be-privatized-before-trumps-term-ends/, 19. 11. 2020).

35 Peterson, C. L., 2016, Consumer Financial Protection Bureau Law Enforcement: An Empirical Review, Tulane Law Review, 90, p. 1057.

36 See PHH Corp. et al. v. Consumer Financial Protection Bureau, suit number 15-1177, U.S. Court of Appeals for the District of Columbia Circuit; Quinn, Melissa, Supreme Court rules structure of CFPB is unconstitutional, 2020, CBS News (June 29, 2020). 
continue to operate, but its director, in light of our decision, must be removable by the president at will," wrote the U.S. Supreme Court. ${ }^{37}$ This judgment does not affect the existence of the CFPB but rather its internal structure and the agency's relationship with other branches, in particular, with the President of the U.S. The main role of the CFPB is "to ensure that the federal consumer financial laws are enforced consistently so that consumers may access markets for financial products, and so that these markets are fair, transparent, and competitive." ${ }^{38}$

The Financial Stability Oversight Council (hereinafter, FSOC), established by Title I of the Dodd-Frank Act, has the power to set aside any of the CFPB regulations if the FSOC decides that the regulation would endanger the safety of the banking system or the stability of the U.S. financial systems. ${ }^{39}$ This is a very important provision because it means that under U.S. federal law financial stability is prioritized over financial consumer protection which supports this article's approach.

In the U.S., credit and debtor information is collected and used in a much more detailed way than in the E.U. The reasons for this are beyond the scope of this article but one important factor is that in the E.U., there are stricter data protection rules than in the U.S. In the aftermath of the 2008 financial crisis, in various E.U. member states positive credit information systems were set up, for example in Hungary. ${ }^{40}$ In the U.S., every consumer has a Fair Isaac Corporation (a.k.a. FICO) Score which is a three-digit number based on the positive and negative credit-related information collected and reported by three national credit bureaus: Experian, Equifax, and TransUnion. ${ }^{41}$ The credit reports prepared and reported by these national credit bureaus do not only include information on any credits (e.g., credit cards, any types of loans, or mortgage) but consumers are strongly incentivized to voluntarily authorize the three national credit bureaus to collect and report information on their payments of utility bills and other regular payment obligations e.g., for mobile phone services and Internet service providers. One of the above-mentioned incentivizing factors is that the FICO Score is frequently relied on in transactions even outside financial services, such as in the course of apartment rentals. Landlords check the FICO Score of future tenants and in the case of a low FICO Score the landlord can reject the tenant's application for a lease.

In terms of financial services, the FICO Score helps lenders determine how likely repayment of a loan will be effected by the consumer. The FICO Score affects how much a consumer can borrow, how many months will be the term of the loan, and how much the loan will cost the consumer (the interest rate). One would

$37 \quad I d$

38 https://www.law.cornell.edu/wex/dodd-frank_title_X, 19. 11. 2020).

39 Supra note 29, 12 U.S.C. $\$ 5513$.

40 See the Central Credit Information System (in Hungarian: "Központi Hitelinformációs Rendszer") which only includes positive or favorable information of consumer creditors. It is based on Act No. CXXII of 2011 on the Central Credit Information System (in Hungarian: "2011. évi CXXII. Törvény a központi Hitelinformációs rendszerről”).

41 The Fair Isaac Corporation ("FICO") was founded in 1956 in the U.S., (https://www.fico. $\mathrm{com} /$, 19. 11. 2020). 
expect that because of the extensive reliance on FICO Scoring, U.S. consumers are more knowledgeable than European consumers in terms of financial services but that is not the case according to a recent empirical study. Financial education (a.k.a. financial literacy of consumers) is low on both sides of the Atlantic, and within the E.U., there are significant differences among the member states. ${ }^{42}$

Financial education is a cornerstone of financial consumer protection; therefore this area should be significantly developed both in the U.S. and the E.U. Schools and agencies should partner to achieve a higher level of financial literacy. This is a matter of private initiatives rather than of law and regulation. However, it could be incentivized e.g., via tax incentives or subsidization of such educational projects and programs.

Finally, in this summary on the post-2008 financial consumer protection developments in the U.S., the Making Homes Affordable Program (hereinafter, MHAP) of the U.S. Treasury is noteworthy. The 2009-2016 MHAP was the Housing program within the Troubled Asset Relief Program (hereinafter, TARP). ${ }^{43}$ TARP provided mortgage relief to homeowners and prevented avoidable foreclosures in order to increase financial stability. ${ }^{44}$ TARP cost in total more than USD 30 billion for the taxpayer which was never (and was never intended to be) recovered..$^{45}$ By contrast, the bailout money financial intermediaries received from the U.S. Federal Government was fully repaid, and with interest. ${ }^{46}$ This is relevant from the perspective of this article because it highlights an important factor policy decision-makers need to consider when regarding financial crisis management, i.e., it costs less for the taxpayer and overall, the consumer is better off if the government intervenes early and generously in a severe financial crisis through the financial intermediary sector than later and through a variety of programs addressed to consumers.

\subsection{THE EUROPEAN UNION}

The chief legal/regulatory elements of the E.U's financial consumer protection efforts include Directive 93/13/EEC (setting minimum requirements regarding unfair terms in consumer contracts), Directive 2008/48/EC (setting

42 See Klapper, L., Lusardi, A., Oudheusden, P. van, 2020, Financial Literacy Around the World: Insights from the Standard \& Poor's Ratings Services Global Financial Literacy Survey, pp. 8 and 21, (https://gflec.org/wp-content/uploads/2015/11/3313-Finlit_Report_FINAL-5.11.16. pdf?x49160, Nov. 19, 2020). [p. 21: "Worldwide, just 1-in-3 adults show an understanding of basic financial concepts." See also detailed information on Europe on page 8 of the report, there are significant differences among E.U. member states, with Romania being the lowest ranking; only $22 \%$ of the population is financially literate.]

43 See the MHAP, U.S. Treasury, (https://www.treasury.gov/initiatives/financial-stability/TARPPrograms/housing/Pages/default.aspx, 19. 11. 2020).

44 Supra note 7; see also U.S. Treasury, Making Home Affordable Program Performance Reports (quarterly reports are available on the website of the U.S. Treasury).

45 See the TARP/Housing, (https://www.treasury.gov/initiatives/financial-stability/reports/Pages/TARP-Tracker.aspx\#Housing, 19. 11. 2020).

46 TARP Tracker, Total TARP Funds Outstanding (Banking), (https://www.treasury.gov/initiatives/financial-stability/reports/Pages/TARP-Tracker.aspx, 19. 11. 2020). 
minimum requirements regarding credit agreements for consumers), and Directive 2005/29/EC (setting minimum requirements for unfair business-to-consumer commercial practices). These directives are implemented in each one of the E.U. member states slightly differently in order to fit the respective member state's legal system. Beyond this two-level legal framework, and the dozens of regulatory agencies in the E.U. and at the member state level, the Court of Justice of the European Union's case law also forms part of the E.U.s legal/regulatory framework of financial consumer protection. ${ }^{47}$ It is apparent from the financial consumer protection Webpage of the European Commission (EC), and from the above list of chief legislative pieces, that the E.U.s consumer protection in financial services is limited to "consumer credit rights, the Standard European Consumer Credit Information form, creditworthiness assessment, debt advice and distance marketing of financial services." 48 In the E.U.s framework, financial consumer credit rights include (1) the right to make informed decisions, (2) the right to change your mind (without giving any reason within 14 days), and (3) the right to pay back ahead of time (without penalty rate). The framework is focused on providing full yet concise and clear information to the consumer. A chief tool of this disclosure effort is the Standard European Consumer Credit Information Form (hereinafter, "SECCI"). ${ }^{49}$

The next segment of the E.U.s efforts in this area is the creditworthiness assessment of the financial consumer. Here, the system is fundamentally different from the U.S. system, in large part because of the stronger data protection rules in the E.U. The European Commission has also addressed the over-indebtedness and debt advice for financial consumers in the E.U. through information gathering and information-sharing at the E.U. government level. ${ }^{50}$

Finally, the European Commission recognizes the challenges related to the exponentially growing digitalization of financial consumer services. Directive 2002/65/EC on distance marketing of financial services aims at ensuring that the financial consumer "receives comprehensive information from the provider and

47 Council Directive 93/13/EEC of 5 April 1993 on unfair terms in consumer contracts (OJ L 95, 21. 4. 1993, p. 29-34) ('Unfair Contract Terms Directive'); Directive 2008/48/EC of the European Parliament and of the Council of 23 April 2008 on credit agreements for consumers and repealing Council Directive 87/102/EEC (OJ L 133, 22. 5. 2008, p. 66-92); Directive 2005/29/EC of the European Parliament and of the Council of 11 May 2005 concerning unfair business-to-consumer commercial practices in the internal market and amending Council Directive 84/450/EEC, Directives 97/7/EC, 98/27/EC and 2002/65/EC of the European Parliament and of the Council and Regulation (EC) No 2006/2004 of the European Parliament and of the Council ('Unfair Commercial Practices Directive') (OJ L 149, 11. 6. 2005, p. 22-39); See also Szilágyi, D., 2019, Financial consumer protection and the European Social Model, (https://publicgoods.eu/financial-consumer-protection-and-european-social-model, 19. 11. 2020).

48 European Commission, Consumer protection in financial services, (https://ec.europa.eu/info/ live-work-travel-eu/consumer-rights-and-complaints/consumer-financial-products-and-services/consumer-protection-financial-services_en, 19. 11. 2020).

49 Ibid.

50 European Commission, 2018, Over-indebtedness and Debt Advice, Conclusions of 2018 Debt Advice Stakeholders Forum, (https://ec.europa.eu/info/sites/info/files/conclusionsdebt_advice_forum_.pdf, 19.11.2020). 
that he/she has the right to withdraw from the contract during a cooling-off peri$o d$. It also prohibits abusive marketing practices and restricts other practices such as unsolicited phone calls and emails." ${ }^{51}$ Additionally, the European Commission has conducted various studies to gain a better understanding of financial consumer behavior vis-à-vis digitalization and the impacts of financial digitalization on the consumer. ${ }^{52}$

These are all very significant and positive developments, yet this article argues that financial consumer protection is a much broader area than the scope indicated on the European Commission's Website, and that it is much more connected to financial stability than to competition law. ${ }^{53}$ This author believes that one of the reasons for this narrow approach of the European Commission is that the different organizational units within the European Commission focus on particular segments of financial consumer protection, as defined broadly by this article, and there is insufficient and insubstantial collaboration among those units to reach a more holistic and efficient approach in the area of financial consumer protection.

The E.U's financial consumer protection framework does define the 'consumer' and neither does it define 'financial consumer protection'. More theoretical work needs to be undertaken in this area of law, it needs to be defined what areas are covered by the term of financial consumer protection. ${ }^{54}$ The existing legal/regulatory framework, including the relevant decisions of the Court of Justice of the European Union, focus on the above-mentioned consumer definition and on an information asymmetry-based justification of consumer protection that is mostly related to consumer lending.

The concept of 'reasonable average consumer' is a cornerstone of this framework. ${ }^{55}$ There are various issues with this approach: most financial consumer services have non-negotiable terms and conditions, therefore, financial consumers are not at a disadvantage in terms of negotiating terms but rather they are not

51 Directive 2002/65/EC of the European Parliament and of the Council of 23 September 2002 concerning the distance marketing of consumer financial services and amending Council Directive 90/619/EEC and Directives 97/7/EC and 98/27/EC (OJ L 271, 9. 10. 2002, p. 16-24); European Commission, Distance marketing of financial services, (https://ec.europa.eu/info/ live-work-travel-eu/consumer-rights-and-complaints/consumer-financial-products-and-services/consumer-protection-financial-services_en, 19. 11. 2020).

52 European Commission, 2019, Behavioural Study on the Digitalisation of the Marketing and Distance Selling of Retail Financial Services, Executive Summary, (https://ec.europa.eu/info/ sites/info/files/live_work_travel_in_the_eu/consumers/digitalisation_of_financial_services_-_executive_summary_-_en_0.pdf, 19. 11.2020).

53 Supra note 22.

54 A 'consumer' is an individual who is acting for purposes which are outside his/her trade, business, or profession; see Directives 93/13/EEC, Article 2(b), and 2008/48/EC, Article 3(a).

55 See Directive 2005/29/EC, Recital (18): "In line with the principle of proportionality, and to permit the effective application of the protections contained in it, this Directive takes as a benchmark the average consumer, who is reasonably well-informed and reasonably observant and circumspect, taking into account social, cultural and linguistic factors, as interpreted by the Court of Justice, but also contains provisions aimed at preventing the exploitation of consumers whose characteristics make them particularly vulnerable to unfair commercial practices." 
in a position to negotiate at all. This, in combination with a low level of financial literacy indicates that it is more efficient to grasp the issues related to financial consumer protection from a systemic stability perspective and consider systemic stability-related institutions, such as deposit insurance and investor compensation schemes, and issues related to data protection as part of the body of law pertaining to financial consumer protection, ${ }^{56}$ which is more related to financial stability than to the narrower area of competition law. The combined competition law-related issues of financial consumer protection constitute only one of the various, areas of this body of law noted above.

This article argues that one of the E.U.s most important efforts regarding financial and general consumer protection is the General Data Protection Regulation (hereinafter, GDPR) which lays down rules for the protection of individuals with regard to the processing and free flow of personal data. ${ }^{57}$ With the exponentially increasing digitalization of financial services, this is a key area of financial consumer protection for two reasons: (1) because of the confidence of the financial consumer in the financial system, and (2) because of the growing scale of digital recording of all types of ownership rights. A strong financial consumer protection in these areas is crucial; both aspects directly and significantly affect the stability of the financial system.

Even though there were stronger consumer protection laws in the E.U. than in the U.S. prior to the 2008 financial crisis, the rules related to the conditions of mortgage lending were not particularly restrictive, and merit regulation was limited in the E.U. For example, there was no specific merit regulation in terms of mortgage rates. Variable interest rates were common, and providing foreign exchange loans, foreign exchange denominated loans, and no-down payment mortgage loans followed the law (see the Hungarian example below). In Europe, prior to the 2008 financial crisis it was a widespread technique to set interest rates by applying London Inter-bank Offered Rate (hereinafter, LIBOR) or other benchmark rates on retail mortgage loans.

Because of the scandalous LIBOR manipulation that endured for six years, and financially harmed millions of consumers, the U.K. has decided to phase out and end the LIBOR from January $2021 .^{58}$ The effects of the LIBOR manipulation were global because the LIBOR was used as a benchmark in terms of the cost of borrowing funds. It was applied to many types of financial instruments, including futures, swaps, options, bonds, and consumer lending products such as mortgages, credit cards, and student loans. ${ }^{59}$ In October 2020, a New York court approved a nearly $\$ 22$ million settlement between a class of indirect investors

56 Supra note 41.

57 See generally Bradford, A., 2020, The Brussels Effect: How the European Union Rules the World, Oxford, U.K., Oxford University Press.

58 Ring, S., 2017, Libor Funeral Set for 2021 as FCA Abandons Scandal-Tarred Rate, Bloomberg (July 27, 2017), (https://www.bloomberg.com/news/articles/2017-07-27/libor-to-end-in2021-as-fca-says-bank-benchmark-is-untenable-j5m5fepe, 19. 11. 2020).

59 Slachetka, M., 2020, Five Banks Settle LIBOR Manipulation Suit for \$22 Million, (https://www. capitalmarketslitigation.com/2020/10/five-banks-settle-libor-manipulation-suit-for-22-million/, 19. 11. 2020). 
and five Wall Street banks that the plaintiff investors accused of manipulating the LIBOR in violation of the Sherman Act. ${ }^{60}$

It is unclear at this point, how financial consumers who were harmed by the LIBOR manipulation (e.g., via their mortgage loans where the LIBOR was used in terms of setting the interest rate for the mortgage) could be placated. The lawsuits and authority matter that will be ongoing for many more years to come illustrate well why a strong financial consumer protection system is a shared interest of both consumers and the financial sector. While consumers need to make more effort to educate themselves, the financial sector needs to realize that the balancing of short- and long-term interests pays off in the long run and that a more cooperative and consumer-focused approach increases confidence in the financial sector and which will be economically beneficial for that sector.

In the aftermath of the 2008 financial crisis, because of the highly technical nature of financial services, in the E.U., specialized authorities were set up and sometimes in parallel with the "general" consumer protection authority, which continued to serve consumers in other sectors of the economy. This has been the case, for example, in Hungary, where there is a National Consumer Protection Authority (in Hungarian: "Nemzeti Fogyasztóvédelmi Hatóság") and in the case of competition law concerns (e.g., misleading information provided to a large number of consumers), the Hungarian Competition Authority (in Hungarian: "Gazdasági Versenyhivatal") is the competent supervisory authority. However, the financial supervisory authority is the Central Bank of Hungary (in Hungarian: "Magyar Nemzeti Bank"), which is the primary authority focused, among other financial supervisory matters, on the enforcement of financial consumer protection laws. ${ }^{61}$

This article argues that the above developments regarding the E.U.'s financial consumer protection efforts are great, yet this area could be further developed for the benefit of consumers if the E.U. would consider the financial stability-related institutions as part of the E.U.'s financial consumer protection framework. All of the elements of the E.U.s financial systemic-stability framework also serve the purpose of financial consumer protection, and ultimately the systemic stability of the financial sector. The European Stability Mechanism (ESM) is the bailout fund of the E.U. that is sustained as a preventative measure during potential periods of severe crises, in order to prevent or attenuate the negative effects of financial failure on the real economy and the society. The European Deposit Insurance (EDIS) scheme will not be completed by 2024. The strengthened Banking Union and the SEPA contribute to the region's competitiveness. Finally, the Bank Recovery and Resolution Directive and the Single Resolution Mechanism also serve the interests of consumers ultimately. ${ }^{62}$ The E.U.s post-2008 financial

60 Id.; see also In re: Libor-based Financial Instruments Antitrust Litigation, index number 1:11-md-02262, U.S. District Court for the Southern District of New York.

61 See also Yearly Financial Consumer Protection Report [in Hungarian: "Pénzügyi fogyasztóvédelmi jelentés"], Central Bank of Hungary, (https://www.mnb.hu/kiadvanyok/jelentesek/penzugyi-fogyasztovedelmi-jelentes, 19. 11. 2020).

62 Curia judgment (Grand Chamber), Case C-526/14, Tadej Kotnik and Others v. Državni zbor Republike Slovenije, Request for a preliminary ruling (judgment No ECLI:EU:C:2016:570) 
stability-related framework is a work-in-progress. This article argues that these systemic stability-related measures and institutions have many more robust benefits for consumers than the competition law-based institutions, which are also very important but they are only one segment of the full picture of financial consumer protection this article aims at highlighting.

\section{CONCLUSION}

Consumer financial services are an especially important segment of the banks' portfolios. A systemic stability-approach of financial consumer protection can add further arguments in favor of strengthening financial consumer protection. Both consumers and the financial sector will benefit from such approach. This article makes four main conclusions: (1) The current framework of financial consumer protection is stronger than before the 2008 financial crisis, however it is not sufficiently robust to have a significantly positive impact on financial stability. (2) A financial stability-based financial-consumer protection approach is suggested over a primarily competition law-based approach. (3) It is more efficient to operate with a more encompassing financial consumer protection definition. (4) Finally, incentivizing is more efficient than merit-regulation because banks provide standardized services and avoid legal risk.

This article notes several examples that support the fact that financial consumer protection is primarily based on systemic stability rather than on any other narrower arguments. For example, the E.U. Retail Payment Strategy is part of the E.U. Financial Stability Framework. ${ }^{63}$ The E.U.s regulatory efforts have far-reaching global effects. ${ }^{64}$ The Directorate-General (DG) for Financial Stability, Financial Services and Capital Markets Union is the European Commission's DG responsible for E.U. policy on banking and finance. The international coordination of consumer financial protection has been a growing area; refer to the International Financial Protection Organization and other organizations mentioned in this article. ${ }^{65}$

(July 19, 2016) ('Kotnik Case'); Directive 2014/59/EU of the European Parliament and of the Council of 15 May 2014 establishing a framework for the recovery and resolution of credit institutions and investment firms and amending Council Directive 82/891/EEC, and Directives 2001/24/EC, 2002/47/EC, 2004/25/EC, 2005/56/EC, 2007/36/EC, 2011/35/EU, 2012/30/ EU and 2013/36/EU, and Regulations (EU) No 1093/2010 and (EU) No 648/2012, of the European Parliament and of the Council ('2014 BRRD').

63 European Commission, Financial Stability, Financial Services and Capital Markets, (https:// ec.europa.eu/info/departments/financial-stability-financial-services-and-capital-marketsunion_en, 19. 11.2020).

64 See generally Bradford, A., 2020.

65 International Financial Protection Organization, (http://www.finconet.org/newsandevents/, Nov. 19, 2020), members of the organization include Australian Securities and Investments Commission, Central Bank of Brazil, Financial Consumer Agency Canada, German Federal Financial Supervisory Authority (BaFin), Indonesian Financial Services Authority (OJK), Central Bank of Ireland, Bank of Italy, Financial Services Agency Japan, Banco de Portugal (Central Bank of Portugal), South African Financial Sector Conduct Authority, Banco de España (Central Bank of Spain). 
The OECD Recommendations include a variety of points regarding financial education, awareness, and digital competence. This article argues that these are the cornerstones of not only financial consumer protection but also of financial stability. ${ }^{66}$ The OECD Recommendations point out that "Governments and stakeholders should work together to educate consumers, government officials and businesses about e-commerce to foster informed decision-making." 67 This article proposes that financial education should start as early as in primary school and should also continue in high school. Universities and research institutes could partner with schools and launch such educational programs. This is in line with the OECD recommendations, according to which "Governments and stakeholders should make use of all effective means to educate consumers and businesses, including innovative techniques made possible by global networks." ${ }^{68}$ A strengthened financial consumer education will be a cornerstone of financial consumer protection and of financial systemic stability in the new digital financial era.

\section{BIBLIOGRAPHY}

1. Blazsek, V., 2020, Banking Bailout Law: A Comparative Study of the United States, United Kingdom and the European Union, New York, U.S., London, U.K., Routledge.

2. Block-Lieb, S., Janger, E. J., 2006, The Myth of the Rational Borrower: Rationality, Behaviorism, and the Misguided 'Reform' of Bankruptcy Law, Texas Law Review, Vol. 84.

3. Bostic, R. W. et al. 2008, State and Local Anti-Predatory Lending Laws: The Effect of Legal Enforcement Mechanisms, Journal of Economics and Business, Vol. 60.

4. Bradford, A., 2020, The Brussels Effect: How the European Union Rules the World, Oxford, U.K., Oxford University Press.

5. Engel, K. C., Fitzpatrick, T. J., 2011, The American Mortgage System: Crisis and Reform [Chapter: Framework for Consumer Protection in Home Mortgage Lending], Philadelphia, U.S., University of Pennsylvania Press.

6. Engel, K. C., McCoy, P., 2011, The Subprime Virus: Reckless Credit, Regulatory Failure, and Next Steps, Oxford, U.K., Oxford University Press.

7. Gerding, E. F., 2009, The Subprime Crisis and the Link Between Consumer Financial Protection and Systemic Risk, FIU Law Review, 4.

8. Janger, E. J., Block-Lieb, S., 2010, Consumer Credit and Competition: The Puzzle of Competitive Credit Markets, European Competition Journal, Vol. 6, No. 68.

9. Kennedy, L. J., McCoy, P. A., Bernstein, E., 2012, The Consumer Financial Protection Bureau: Financial Regulation for the Twenty-First Century, Cornell Law Review, 97 (http://scholarship.law.cornell.edu/clr/vol97/iss5/4, 19. 11. 2020).

10. Loo, R. van, 2019, Broadening Consumer Law: Competition, Protection, and Distribution, Notre Dame Law Review, Vol. 95, Issue 1.

11. McLean, B., Nocera, J., 2010, All the Devils are Here, The Hidden History of the Financial Crisis, New York, U.S., Portfolio/Penguin.

66 Supra note 9, at points 50-52, p. 18.

67 Id. at 50.

$68 I d$. at 52 (see also at 53). 
12. Peterson, C. L., 2016, Consumer Financial Protection Bureau Law Enforcement: An Empirical Review, Tulane Law Review, 90.

\section{LEGISLATIVE SOURCES}

1. Act No. CXXII of 2011 on the Central Credit Information System [in Hungarian: “2011. évi CXXII. Törvény a központi Hitelinformációs rendszerről”].

2. Council Directive 93/13/EEC of 5 April 1993 on unfair terms in consumer contracts (OJ L 95, 21. 4. 1993, p. 29-34) ('Unfair Contract Terms Directive').

3. Directive 2008/48/EC of the European Parliament and of the Council of 23 April 2008 on credit agreements for consumers and repealing Council Directive 87/102/ EEC (OJ L 133, 22. 5. 2008, p. 66-92).

4. Directive 2005/29/EC of the European Parliament and of the Council of 11 May 2005 concerning unfair business-to-consumer commercial practices in the internal market and amending Council Directive 84/450/EEC, Directives 97/7/EC, 98/27/EC and 2002/65/EC of the European Parliament and of the Council and Regulation (EC) No 2006/2004 of the European Parliament and of the Council ('Unfair Commercial Practices Directive') (OJ L 149, 11. 6. 2005, p. 22-39).

5. Directive 97/9/EC of the European Parliament and of the Council of 3 March 1997 on investor-compensation schemes (OJ L 084, 26. 3. 1997, p. 22-31) ('Investor Compensation Scheme Directive').

6. Directive 2014/49/EU of the European Parliament and of the Council of 16 Apr. 2014 on deposit guarantee schemes (OJ L 173 of 12 June 2014) ('Deposit Guarantee Scheme Directive').

7. Directive 2014/59/EU of the European Parliament and of the Council of 15 May 2014 establishing a framework for the recovery and resolution of credit institutions and investment firms and amending Council Directive 82/891/EEC, and Directives 2001/24/EC, 2002/47/EC, 2004/25/EC, 2005/56/EC, 2007/36/EC, 2011/35/ EU, 2012/30/EU and 2013/36/EU, and Regulations (EU) No 1093/2010 and (EU) No 648/2012, of the European Parliament and of the Council ('2014 BRRD').

8. Directive 2002/65/EC of the European Parliament and of the Council of 23 September 2002 concerning the distance marketing of consumer financial services and amending Council Directive 90/619/EEC and Directives 97/7/EC and 98/27/EC (OJ L 271, 9. 10. 2002, p. 16-24).

9. Dodd-Frank Wall Street Reform and Consumer Protection Act (Pub L 111-203, H.R. 4173) (7/21/2010), Title X, (https://www.law.cornell.edu/wex/dodd-frank_title_X, 19. 11.2020).

\section{CASE LAW}

1. In re: Libor-based Financial Instruments Antitrust Litigation, index number 1:11-md02262, U.S. District Court for the Southern District of New York, NY, U.S.

2. Curia judgment (Grand Chamber), Case C-526/14, Tadej Kotnik and Others v. Državni zbor Republike Slovenije, Request for a preliminary ruling (judgment No ECLI:EU:C:2016:570) (July 19, 2016) ('Kotnik Case').

3. PHH Corp. et al. v. Consumer Financial Protection Bureau, suit number 15-1177, U.S. Court of Appeals for the District of Columbia Circuit. 


\section{INTERNET SOURCES}

1. Ausick, P., 2020, Do Investors Think Fannie Mae, Freddie Mac Can Be Privatized Before Trump's Term Ends?, Blog Post, 247WALLST, (https://247wallst.com/bankingfinance/2020/11/23/do-investors-think-fannie-mae-freddie-mac-can-be-privatizedbefore-trumps-term-ends/, 19. 11. 2020).

2. Blazsek, V., 2020, Banking Bailout Law, Blue Sky Blog, Columbia Law School, (https://clsbluesky.law.columbia.edu/2020/10/22/banking-bailout-law/22. 10. 2020).

3. CFPB, 2020, Consumer Financial Protection Bureau, (https://www.consumerfinance. gov/, 19. 11. 2020).

4. eConsumer.gov, 2020, (https://econsumer.gov/\#crnt, 19. 11. 2020).

5. European Commission, Consumer protection in financial services, (https://ec.europa. eu/info/live-work-travel-eu/consumer-rights-and-complaints/consumer-financialproducts-and-services/consumer-protection-financial-services_en, 19. 11. 2020).

6. European Commission, Distance marketing of financial services, (https://ec.europa. eu/info/live-work-travel-eu/consumer-rights-and-complaints/consumer-financialproducts-and-services/consumer-protection-financial-services_en, 19. 11. 2020).

7. European Commission, 2018, Over-indebtedness and Debt Advice, Conclusions of 2018 Debt Advice Stakeholders Forum, (https://ec.europa.eu/info/sites/info/files/ conclusionsdebt_advice_forum_.pdf, 19.11.2020).

8. FICO (The Fair Isaac Corporation), 2020, (https://www.fico.com/, 19. 11. 2020).

9. G20, 2011, High-Level Principles on Financial Consumer Protection, (http://www. oecd.org/daf/fin/financial-markets/48892010.pdf, 19. 11. 2020).

10. International Consumer Protection and Enforcement Network, (https://icpen.org/initiatives, 19. 11. 2020).

11. International Financial Consumer Protection Organisation ("FinCoNet"), (http:// www.finconet.org/about/, 19. 11. 2020).

12. International Financial Consumer Protection Organization ("FinCoNet"), (http:// www.finconet.org/newsandevents/, 19. 11. 2020).

13. MHAP, (https://www.treasury.gov/initiatives/financial-stability/TARP-Programs/housing/Pages/default.aspx, 19. 11. 2020).

14. OECD, (http://www.oecd.org/sti/consumer/consumersinthedigitaleconomy.htm, 19. 11. 2020).

15. OECD Directorate for Science, Technology and Innovation, Consumer policy, (http:// www.oecd.org/sti/consumer/, 19. 11. 2020).

16. OECD, Financial Consumer Protection, (http://www.oecd.org/daf/fin/financial-markets/financialconsumerprotection.htm, 19. 11. 2020).

17. Szilágyi, D., 2019, Financial consumer protection and the European Social Model, (https://publicgoods.eu/financial-consumer-protection-and-european-social-model, 19. 11. 2020).

18. TARP/Housing, (https://www.treasury.gov/initiatives/financial-stability/reports/Pages/TARP-Tracker.aspx\#Housing, 19. 11. 2020).

19. TARP Tracker, Total TARP Funds Outstanding (Banking), (https://www.treasury.gov/ initiatives/financial-stability/reports/Pages/TARP-Tracker.aspx, 19. 11. 2020).

20. United Nations, Global Compact, Sustainable Finance, (https://www.unglobalcompact.org/sdgs/sustainablefinance, 19. 11. 2020). 


\section{OTHER SOURCES}

1. BIS, Basel III: international regulatory framework for banks, (https://www.bis.org/ bcbs/basel3.htm?m=3\%7C14\%7C572, 19. 11. 2020).

2. Central Bank of Hungary, Yearly Financial Consumer Protection Report [in Hungarian: "Pénzügyi fogyasztóvédelmi jelentés”], 2020, (https://www.mnb.hu/kiadvanyok/ jelentesek/penzugyi-fogyasztovedelmi-jelentes, 19. 11. 2020).

3. ECB determined Banco Popular Español S.A. was failing or likely to fail, 2017, ECB Press Release, (https://www.bankingsupervision.europa.eu/press/pr/date/2017/html/ ssm.pr170607.en.html, 19. 11. 2020).

4. European Commission, 2019, Behavioural Study on the Digitalisation of the Marketing and Distance Selling of Retail Financial Services, Executive Summary, (https:// ec.europa.eu/info/sites/info/files/live_work_travel_in_the_eu/consumers/digitalisation_of_financial_services_-_executive_summary_-_en_0.pdf, 19. 11. 2020).

5. European Commission, 2020, Financial Stability, Financial Services and Capital Markets Union, (https://ec.europa.eu/info/departments/financial-stability-financial-services-and-capital-markets-union_en, 19. 11.2020).

6. Klapper, L., Lusardi, A., Oudheusden, P. van, 2020, Financial Literacy Around the World: Insights from the Standard \& Poor's Ratings Services Global Financial Literacy Survey, (https://gflec.org/wp-content/uploads/2015/11/3313-Finlit_Report_FINAL-5.11.16.pdf?x49160, 19. 11. 2020).

7. OECD, Recommendation on Consumer Protection for E-commerce, 2016, (http:// www.oecd.org/sti/consumer/ECommerce-Recommendation-2016.pdf, 19. 11. 2020).

8. Quinn, M., Supreme Court rules structure of CFPB is unconstitutional, CBSNEWS (29. 6. 2020).

9. Ring, S., 2017, Libor Funeral Set for 2021 as FCA Abandons Scandal-Tarred Rate, Bloomberg, (https://www.bloomberg.com/news/articles/2017-07-27/libor-to-end-in2021-as-fca-says-bank-benchmark-is-untenable-j5m5fepe, 19. 11. 2020).

10. Slachetka, M., 2020, Five Banks Settle LIBOR Manipulation Suit for \$22 Million, (https://www.capitalmarketslitigation.com/2020/10/five-banks-settle-libor-manipulation-suit-for-22-million/, 19. 11. 2020).

11. United Nations, A Global Compact for Sustainable Development, (https://d306pr3pise04h.cloudfront.net/docs/issues_doc\%2Fdevelopment\%2FGCforSDbrochure.pdf, 19. 11. 2020).

12. U.S. Treasury, Making Home Affordable Program Performance Reports, 19. 11. 2020).

13. World Bank, Good Practices for Financial Consumer Protection, 2017, (https://www. worldbank.org/en/topic/financialinclusion/brief/2017-good-practices-for-financialconsumer-protection, 19. 11. 2020). 


\title{
ZAŠTITA KORISNIKA FINANSIJSKIH USLUGA U SAD I EU. PREVENTIVNO IZGRAĐEN SISTEM PROPISA O SANACIJI BANAKA KORIŠĆENJEM BUDŽETSKIH SREDSTAVA
}

\author{
Virág Blazsek
}

\section{REZIME}

Trenutni pravni /regulatorni okvir finansijske zaštite potrošača u SAD i EU je sada jači nego što je bio pre globalne finansijske krize 2008. godine. Međutim, u ovom članku se tvrdi da finansijska zaštita potrošača trenutno nije dovoljno efikasna da bi izvršila značajniji pozitivni uticaj na finansijsku stabilnost. U članku su date različite sugestije u smislu kako da se ovo promeni i predlaže se nova analiza okvira za zaštitu korisnika finansijskih usluga posle 2008. godine u SAD i EU. Prvo, predlaže se jačanje zaštite potrošača koristeći širi sistemski argument zasnovan na stabilnosti, a ne uži argument koji se zasniva na propisima o zaštiti konkurencije. Iz perspektive sistemske stabilnosti, finansijska zaštita potrošača je mnogo šire područje od nelojalne komercijalne prakse, u slučajevima kao što su obmanjujuće informacije ili zloupotreba dominantnog položaja. Drugo, predlaže se sveobuhvatnija definicija zaštite potrošača, katalog glavnih oblasti i instrumenata zaštite i interdisciplinarniji pristup u ovoj novoj eri. Brz tehnološki razvoj, digitalizacija i sve veća koncentracija na tržištu preoblikovali su finansijski sektor i druge sektore privrede. Adekvatna zaštita potrošača postaje još važnija kako asimetrija između položaja potrošača i pružaoca finansijskih usluga postaje sve veća. Moguće je da je upravo zbog ovih novih izazova u poslednje vreme došlo do međunarodne institucionalizovane saradnje u ovoj oblasti prava. Ovaj članak se nadovezuje na činjenicu da je finansijska stabilnost zajednički interes potrošača i finansijskog sektora, a takođe se naglašava važnost finansijskog obrazovanja koje bi trebalo razviti na obe strane Atlantika.

Ključne reči: finansijska zaštita potrošača, finansijska stabilnost, sanacija, finansijsko obrazovanje, finansijska pismenost, međunarodna zaštita potrošača, EU finansijska zaštita potrošača, Biro za finansijsku zaštitu potrošača, Dodd-Frank zakon, sanacija banaka i EU direktive. 